\title{
Morphological characteristics of goat breeds in Nigeria using discriminant analysis approach \\ ${ }^{*}{ }^{1}$ Rotimi, E. A., ${ }^{1}$ Aliyu, A. M. and ${ }^{1}$ Aruwayo, A. \\ *I Department of Animal Science, Federal University Dutsin-Ma, Katsina State, Nigeria \\ Corresponding author: ${ }^{1}{ }^{1}$ earotimi@gmail.com; \\ Abstract +2347037968698; 0000-0002-5657-6151
}

Information on morphological characteristics is a prerequisite to sustainable breed classification and conservation for proper management and utilization. The present study aimed to identify morphological characteristics that best classify the Sahel, Sokoto Red and West African Dwarf goats of Nigeria. A total of 584 goats of both sexes; Sahel $(N=163)$, Sokoto Red $(N=171)$ and West African Dwarf $(N=250)$ were randomly sampled and used for this study. The body parameters measured included body weight (BWT), height at wither $(H W)$, body length $(B L)$, paunch girth $(P G)$, heart girth $(H G)$ and ear length (EL). Multivariate technique of discriminant analysis procedure of SPSS 20.0 statistical package was used to classify the Sahel, Sokoto Red and West African Dwarf goats into their original breed. Accuracy of the classification was checked using cross-validation (leave-one-out, jack-knife or split-sample) procedure. Results showed that the mean body weight (kg) of Sokoto Red was significantly $(P<0.05)$ higher than those of Sahel and West African Dwarf goats (23.596, 17.117 and 14.800 respectively). Highest correlation values were recorded between body weight and height at withers (0.777) in Sahel, body weight and paunch girth (0.707) in Sokoto Red and body weight and heart girth (0.797) in West African Dwarf goats. The discriminant analysis on body weight and the linear body measurements revealed that paunch girth and height at withers were the most discriminating variables and clearly separated and classified the three goat breeds into their breeds of origin. The discriminant function obtained correctly classified $99.0 \%$ of individuals from the sample of known goat populations. The classification accuracy of the function was cross-validated using the splitsample method, and indicated a 99.0\% success rate $(97.5 \%, 100.0 \%$ and $99.2 \%$ of Sahel, Sokoto Red and West African Dwarf goats respectively). It was concluded that there was a clear separation between Barcha and Atlas goats. It was concluded that discriminant tool may be used successfully in the field to classify Sahel, Sokoto Red and West African Dwarf in the field, however there is need to complement this with molecular characterization using DNA marker for better conservation and improvement programme of indigenous goat genetic resources.

Keywords: Breeds, discriminant analysis, morphological traits, multivariate

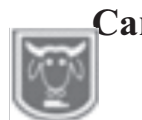

Caractéristiques morphologiques des races caprines au Nigeria en utilisant l'approche d'analyse discriminante

\section{Résumé}

L'information sur les caractéristiques morphologiques est une condition préalable à la classification et à la conservation durables des races pour une gestion et une utilisation appropriées. Cet étude visait à identifier les caractéristiques morphologiques qui classent le mieux les chèvres sahéliennes, rouges de Sokoto et naines d'Afrique de l'Ouest du Nigeria. Un total de 584 chèvres des deux sexes ; Sahel $(N=163)$, Sokoto Red $(N=171)$ et West African $\operatorname{Dwarf}(N=250)$ ont été échantillonnés au hasard et utilisés pour cette étude. Les paramètres corporels mesurés comprenaient le poids corporel (PC), la hauteur au garrot (HG), la 


\section{Morphological characteristics of goat breeds in Nigeria}

longueur du corps (BL), la circonférence de la panse (CP), la circonférence du cœur (CC) et la longueur des oreilles (LO). La technique multivariée de la procédure d'analyse discriminante du progiciel statistique SPSS 20.0 a été utilisée pour classer les chèvres sahéliennes, rouges de Sokoto et naines d'Afrique de l'Ouest dans leur race d'origine. L'exactitude de la classification a été vérifiée à l'aide d'une procédure de validation croisée (en laisser un, un couteau ou un échantillon divisé). Les résultats ont montré que le poids corporel moyen $(\mathrm{kg})$ de Sokoto Red était significativement $(P<0,05)$ supérieur à celui des chèvres naines du Sahel et d'Afrique de l'Ouest (23,596, 17,117 et 14,800 respectivement). Les valeurs de corrélation les plus élevées ont été enregistrées entre le poids corporel et la hauteur au garrot $(0,777)$ au Sahel, le poids corporel et la circonférence de la panse $(0,707)$ chez le Sokoto Red et le poids corporel et la circonférence cardiaque $(0,797)$ chez les chèvres naines d'Afrique de l'Ouest. L'analyse discriminante sur le poids corporel et les mesures corporelles linéaires ont révélé que la circonférence de la panse et la hauteur au garrot étaient les variables les plus discriminantes et ont clairement séparé et classé les trois races caprines dans leurs races d'origine. La fonction discriminante obtenue a correctement classé 99,0\% des individus de l'échantillon de populations caprines connues. La précision de la classification de la fonction a été contre-validée à l'aide de la méthode de l'échantillon divisé et a indiqué un taux de réussite de 99,0\% (respectivement 97,5\%, 100,0\% et 99,2\% des chèvres sahéliennes, rouges de Sokoto et naines d'Afrique de l'Ouest). Il a été conclu qu'il y avait une nette séparation entre les chèvres Barcha et Atlas. Il a été conclu que l'outil discriminant peut être utilisé avec succès sur le terrain pour classer le Sahel, le rouge de Sokoto et le nain d'Afrique de l'Ouest sur le terrain, mais il est nécessaire de le compléter par une caractérisation moléculaire à l'aide d'un marqueur ADN pour une meilleure conservation et un programme d'amélioration de la génétique caprine indigène. Ressources.

Mots-clés : Races, analyse discriminante, traits morphologiques, multivarié.

\section{Introduction}

Goats are the most numerous of all domesticated ruminants in Nigeria with an estimated population of 79.38 million, representing about $6.56 \%$ of the world's goat population (FAOSTAT, 2018). Goats play very significant role in the social and economic livelihoods of rural dwellers, they constitute significant source of milk, meat and skin; goats also serve as a source of income (Adebambo et al., 2011). Information on morphological characteristics is a prerequisite to sustainable breed improvement, utilization and conservation (FAO, 2012). Multivariate analyses using morphological traits have been proved to be suitable in assessing the variation within a population and can discriminate different population (Dossa et al., 2007). Breeds are a homogenous, subspecific groups of domestic livestock with definable and identifiable external characteristics that enable it to be classified, using visual appraisal, from other similarly defined groups within the same species (FAO 2000). Discriminant analysis is a statistical procedure to visually classify species or breeds that are morphologically distinct (Setiaji et al., 2012). Discriminant analysis uses a set of prediction equations based on independent variables that are used to classify individuals into groups, thereby reducing errors of selection for future improvement programmes (Yakubu et al., 2010).

Some researchers have used discriminant analysis procedures to classify various farm animals into groups using; morphometric parameters on West African Dwarf and Red Sokoto goats (Yakubu et al., 2010), body weight and linear body measurements on three Saudi goat types (Aziz and Al-Hur, 


\section{Rotimi, Aliyu and Aruwayo}

2013), morphometric on West African Dwarf Goats in south-eastern Nigeria (Ebegbulem et al., 2011) and morphometric characterization of Nigerian indigenous sheep (Yunusa et al., 2013). Discriminant analysis allows us to understand the differences between populations and predict the class or group which individuals belong to. The objective of the present study was to evaluate morphological characteristics of the three Nigerian indigenous goat breeds using discriminant analysis approach. The information obtained from this study will provide basis for effective identification, conservation, management and utilization of the goat genetic resources in Nigeria.

\section{Materials and methods}

\section{Description of the study location}

The study was carried out across locations in three States (Benue, Katsina and Sokoto states) of Nigeria. Locations were selected based on the preponderance of the breed in the area.

\section{Experimental animals and management}

Three Nigerian indigenous goat breeds, namely: Sahel (SAH), Sokoto Red (SOR) and West African Dwarf (WAD) were used for this study. A total of 584 goats; Sahel (N $=163)$, Sokoto Red $(\mathrm{N}=171)$ and West African Dwarf $(\mathrm{N}=250)$ were randomly sampled for this study. Both sexes were included in the study. The goats were managed under extensive system where they grazed during the day on natural pasture containing forages and scavenged on farm residues and kitchen wastes when and as available.

\section{Data collection}

Data were collected on five hundred and eighty-four (584) goats. Data were taken on individual goats. All measurements were taken on goats that are apparently healthy and phenotypically conformed to the classification description of each breed. Before measuring various parameters, the goats were restrained and calmed properly. Measurements were done early in the morning to avoid the effect of feeding and watering on the goats' size and conformation. Measurements on body lengths and circumferences (in $\mathrm{cm}$ ) were obtained using flexible measuring tape, while the height measurements (in $\mathrm{cm}$ ) were taken using graduated meter ruler. All the linear, girth and height measurements were taken to the nearest $0.5 \mathrm{~cm}$. The reference points and procedure for the body measurements were in accordance with the methods described by FAO (2012), Akpa et al. (2014) and Rotimi et al. (2020).

\section{Traits measured}

The morphological traits measured were;

1. Body weight (BWT): The live body weight (in $\mathrm{kg}$ ) was obtained by using a top-loader weighing scale.

2. Height at Wither (HW): The vertical distance from the top of the shoulder to the ground (in $\mathrm{cm}$ ).

3. Body Length (BL): This was taken as the horizontal length from the point of shoulder to the pin bone (in cm).

4. Paunch girth (PG): This is the body circumference taken around the umbilicus (in cm).

5. Heart girth (HG): The circumference of the chest posterior to the forelegs at right angles to the body axis. This is also called Chest Girth (in cm).

6. Ear Length (EL): This is the length of the external ear from its root to the tip (in $\mathrm{cm}$ ).

\section{Data analysis}

\section{Morphological data}

Data generated on the morphological traits were subjected to Analysis of Variance (ANOVA) using the SPSS 20.0 (2011) statistical package to test the effects of breed on the measured parameters. Mean separation was done using Duncan Multiple Range Test (DMRT) statistical procedures. The model employed was; 


\section{Morphological characteristics of goat breeds in Nigeria}

$\mathrm{Y}_{\mathrm{ij}} \quad=\quad \mu+\mathrm{B}_{\mathrm{i}}+\mathrm{e}_{\mathrm{ij}}$

Where;

$\mathrm{Y}_{\mathrm{ij}}=$ Single observation on body weight or linear body measurements.

$\mu=$ Overall mean

$\mathrm{B}_{\mathrm{i}}=$ Fixed effect of breed $(\mathrm{i}=1,2,3)$

$\mathrm{e}_{\mathrm{ij}}=$ Random error effect associated to the observation

\section{Phenotypic correlation}

Pearson's correlation coefficient was computed between the body weight and morphological traits using SPSS 20.0 (2011) statistical package.

\section{Discriminant analysis}

The discriminant analysis procedure was employed to estimate the proportion of goats that were properly classified into their original breed using SPSS 20.0 (2011) statistical package. Accuracy of the classification was checked using crossvalidation (leave-one-out, jack-knife or split-sample) procedure. The percentage of mis-classified goats indicates the degree of admixture between the breeds.

\section{Results and discussion Morphological traits}

Table 1 shows the descriptive statistics of the body weight and linear measurements of the three Nigerian goat breeds. Body weight $(\mathrm{kg})$ was significantly $(\mathrm{P}<0.05)$ higher in SOR than in SAH and WAD (23.596, 17.117 and 14.375 respectively). There were significant $(\mathrm{P}<0.05)$ difference in the linear body measurements, with $\mathrm{SAH}$ having higher values. Results showed more variability for body weight among the breeds $(35.485 \%, 34.375 \%$ and $33.541 \%$ for $\mathrm{SAH}, \mathrm{SOR}$ and WAD respectively). The results of this study were slightly higher than the report of Popoola and Oseni (2017) on sheep. The varying coefficients of variation obtained in this study could be attributed to breed differences or influence of the environment on the parameters.

\section{Correlation coefficients for the morphological traits of the three goat breeds}

Tables 2-4 show the correlation coefficients among the morphological traits for West African Dwarf, Sokoto Red and Sahel goat breeds. The phenotypic correlation values (r) were all positive and significant $(\mathrm{P}<$ 0.01) in West African Dwarf, Sokoto Red and Sahel goat breeds. High correlation values were also recorded across the breeds. The highest values recorded were; 0.777 between BWT and HW in Sahel goats, 0.739 between HG and HW in Sokoto Red goats and 0.797 between BWT and HG in West African Dwarf goats. The high, positive and significant $(\mathrm{P}<0.01)$ relationships between the body weight and other traits in West African Dwarf, Sokoto Red and Sahel goat breeds observed in the present study indicated that an increase in any one of these traits would result in an increase in the body weight. This indicates that HW, BL, PG and HG may be effective in predicting body weight, and their selection can lead to the improvement of body weight. This result is similar to the report of Ogah et al. (2013) for West African Dwarf goat breeds, Adeyinka and Mohammed (2006) for Sokoto Red and Sahel goat breeds. Okpeku et al. (2011) also reported similar results for West African Dwarf and Sokoto Red goat breeds. The relationships existing among linear body traits provide useful information on performance, productivity and carcass characteristics of farm animals (Ngere, 2006) and have been found useful in quantifying body size (Ibe and Ezekwe, 1994). The quantitative measurements for size and shape are necessary for estimating genetic parameters in animal breeding programmes (Chineke, 2000). 


\section{Rotimi, Aliyu and Aruwayo}

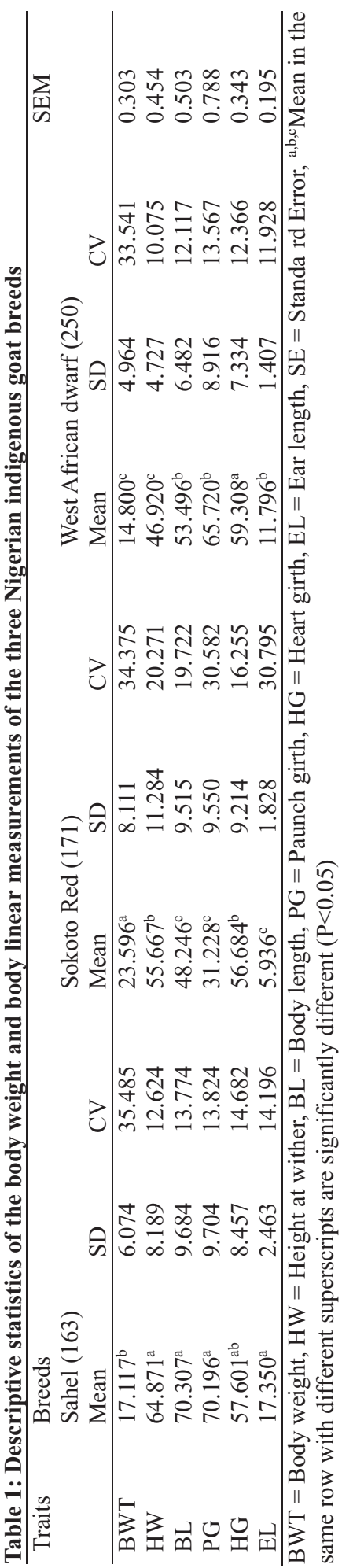




\section{Morphological characteristics of goat breeds in Nigeria}

Table 2: Correlation coefficients between body weight and linear body measurements in Sahel goats

\begin{tabular}{llllll}
\hline Traits & BWT & HW & BL & PG & HG \\
\hline HW & $0.777^{* *}$ & & & & \\
BL & $0.723^{* *}$ & $0.673^{* *}$ & & & \\
PG & $0.754^{* *}$ & $0.733^{* *}$ & $0.718^{* *}$ & & \\
HG & $0.712^{* *}$ & $0.768^{* *}$ & $0.478^{* *}$ & $0.752^{* *}$ & \\
EL & $0.471^{* *}$ & $0.484^{* *}$ & $0.309^{* *}$ & $0.452^{* *}$ & $0.520^{* *}$ \\
\hline
\end{tabular}

$\overline{\mathrm{BWT}}=$ Body weight, $\mathrm{HW}=$ Height at wither, $\mathrm{BL}=$ Body length, $\mathrm{PG}=$ Paunch girth, $\mathrm{HG}=$ Heart girth, $\mathrm{EL}$

$=$ Ear length, ${ }^{* *}$ Correlation is significant at the 0.01 level (2-tailed).

Table 3: Correlation coefficients between body weight and linear body measurements in Sokoto Red goats

\begin{tabular}{llllll}
\hline Traits & BWT & HW & BL & PG & HG \\
\hline HW & $0.465^{* *}$ & & & & \\
BL & $0.515^{* *}$ & $0.512^{* *}$ & & & \\
PG & $0.707^{* *}$ & $0.490^{* *}$ & $0.206^{* *}$ & & \\
HG & $0.407^{* *}$ & $0.739^{* *}$ & $0.612^{* *}$ & $0.273^{* *}$ & \\
EL & $0.578^{* *}$ & $0.403^{* *}$ & $0.308^{* *}$ & $0.703^{* *}$ & $0.480^{* *}$ \\
\hline
\end{tabular}

BWT $=$ Body weight, $\mathrm{HW}=$ Height at wither, $\mathrm{BL}=$ Body length, $\mathrm{PG}=$ =Paunch girth, $\mathrm{HG}=$ Heart girth, EL

$=$ Ear length, ${ }^{* *}$ Correlation is significant at the 0.01 level (2-tailed).

Table 4: Correlation coefficients between body weight and linear body measurements in West African Dwarf goats

\begin{tabular}{|c|c|c|c|c|c|}
\hline Traits & BWT & HW & $\mathrm{BL}$ & PG & $\mathrm{HG}$ \\
\hline HW & $0.617^{* *}$ & & & & \\
\hline BL & $0.736^{* *}$ & $0.709^{* *}$ & & & \\
\hline PG & $0.742^{* *}$ & $0.588^{* *}$ & $0.705^{* *}$ & & \\
\hline $\mathrm{HG}$ & $0.797^{* *}$ & $0.637^{* *}$ & $0.751^{* *}$ & $0.767^{* *}$ & \\
\hline EL & $0.412^{* *}$ & $0.552^{* *}$ & $0.545^{* *}$ & $0.410^{* *}$ & $0.461^{* *}$ \\
\hline
\end{tabular}

\section{Discriminant analysis}

Table 5 shows the results of the tests for the Eigen values and Wilks' lambda. From the Table, the first function explained $83.2 \%$ of the total variation and had a small lambda of 0.013 and significant $(P<0.01)$. The second function explained only $16.8 \%$ of the variance in the data set and significant $(P<$ 0.01) with lambda of 0.228 . The two functions contributed significantly in the discrimination process, having high canonical correlation values of 0.971 and 0.879 , respectively. Table 6 shows the single standardized canonical discriminant function extracted in this study. The standardized canonical correlation coefficients show the individual contribution of independent variables to the prediction of the dependent variable. The discriminating power of paunch girth in the standardized canonical discriminant function 1 was highest (0.954), while height at wither was the highest (0.976) in the second discriminating function. Table 7 shows the results of the discriminant analysis. The results showed that $99.0 \%$ of the animals were correctly classified, leaving $1.0 \%$ rate of misplacement. Crossvalidation with the split-sample method also indicated $99.0 \%$ success rate. The use of cross-validation option provided a better assessment of classification accuracy. About $97.5 \%$ of Sahel goats, $100.0 \%$ of Sokoto Red goats and $99.2 \%$ of West African Dwarf goats were correctly classified into their distinct genetic groups (Figure 1). The use of cross-validation procedures provided a better assessment of 


\section{Rotimi, Aliyu and Aruwayo}

classification accuracy. Thus, every data point was reclassified as if it were a new unknown observation; this provided a more conservative accuracy assessment. The unstandardized canonical discriminant function was used for classification of the individual goats. The variables included in the discriminant (D) equations are; body weight (BWT), height at wither (HW), body length (BL), paunch girth (PG), heart girth (HG) and ear length (EL). The discriminating power of paunch girth and height at withers in the standardized canonical discriminant functions 1 and 2 ( 0.954 and 0.976 , respectively) showed that these two variables are highly important variables in classifying the goat breeds. Ibnelbachyr et al. (2015) reported that the most discriminating traits between the Moroccan goat populations were body length, heart girth, hair length, horn length, ear length and live body weight while Zaitoun et al. (2005) indicated that nose shape was the most discriminating variable among goat breeds of Jordan, followed by withers height then body weight and ear type. Yakubu et al. (2010) revealed that rump height, body length, horn length, face length, chest girth, neck circumference and head width were the most important morphometric traits permitting discrimination between West African Dwarf and Red Sokoto goats in Nigeria. Jimcy et al. (2011) reported that head width, height at withers, chest depth, rump length, rump width, shin circumference and body length, were the most discriminating traits among the goat populations from India. Aziz and Al-Hur (2013) reported that ear length and canon circumference were the most discriminating variables among the three Saudi goat breeds. The results obtained in this study showed that $97.5 \%$ SAH, $100.0 \%$ SOR and 99.2\% WAD were correctly classified respectively. The results, after cross-validation, showed that
$99.0 \%$ of the animals were correctly classified into their classes, leaving only $1.0 \%$ of the animals that were misclassified in this study. This is close to the values reported by Yakubu et al. (2010), who also correctly assigned $99.4 \%$ of WAD and $100 \%$ of RS goats into their distinct genetic groups. The high percentage of correct classification of the individual goats into their respective breeds indicated that the discriminant function is an appropriate tool for correct placement of breeds and hence may help in selective breeding in future breeding programmes. Only about $1.0 \%$ of the animals were misclassified in this study. Traore et al. (2008) correctly classified $79.3 \%$ of Sudan and $82.7 \%$ of Sudan-Sahel goat populations of Burkina Faso into their respective population. Dossa et al. (2007) also correctly classified more than $70 \%$ of goats from Benin into their distinct populations. However, Hirbo et al. (2006) obtained a low percentage in classification in their study and concluded that the low classification correctness obtained in their report may be an indication of either high gene flow or as low power to assign because of too few variables used in analysis. Kunene et al. (2007) also reported that information derived from linear body measurements could be used to complement genetic analyses to develop proper conservation and utilization programmes.

The two functions contributed significantly in the discrimination process, having high canonical correlation values of 0.971 and 0.879 respectively. The two derived canonical discriminant functions discriminating the three goat breeds are as follows:

CAN1 $=-6.299-0.176$ BWT $-0.024 \mathrm{HW}+$ $0.058 \mathrm{BL}+0.102 \mathrm{PG}-0.044 \mathrm{HG}+0.361 \mathrm{EL}$ $\mathrm{CAN} 2=-1.871+0.034 \mathrm{BWT}+0.11 \mathrm{HW}+$ $0.047 \mathrm{BL}-0.085 \mathrm{PG}-0.107 \mathrm{HG}+0.263 \mathrm{EL}$ 


\section{Morphological characteristics of goat breeds in Nigeria}

Table 5: Results of the Eigenvalues and Wilks' Lambda Tests

\begin{tabular}{cll}
\hline Tests & \multicolumn{1}{c}{ Functions } \\
\hline Test of Eigen values & 1 & 2 \\
Eigenvalue & 16.763 & 3.392 \\
Variance (\%) & 83.2 & 16.8 \\
$\quad$ Cumulative variance (\%) & 83.2 & 100.0 \\
$\quad$ Canonical Correlation & 0.971 & 0.879 \\
Wilks' Lambda Tests & & \\
Wilks' Lambda & 0.013 & 0.228 \\
Chi-square & 2520.426 & 856.026 \\
Df & 12 & 5 \\
Sig. & 0.000 & 0.000 \\
\hline
\end{tabular}

$\mathrm{Df}=$ degree of freedom, Sig. $=$ significant

Table 6: Canonical discriminant function coefficients

\begin{tabular}{lll}
\hline Variables & \multicolumn{2}{c}{ Functions } \\
\hline BWT & 1 & 2 \\
HW & -1.116 & 0.217 \\
BL & -0.192 & 0.976 \\
PG & 0.487 & 0.399 \\
HG & 0.954 & -0.794 \\
EL & -0.358 & -0.882 \\
BWT = body weight, $\mathrm{HW}=$ height at wither, $\mathrm{BL}=$ body length, $\mathrm{PG}=$ paunch girth, $\mathrm{HG}=$ heart girth, EL \\
= ear length.
\end{tabular}

Table 7: Results of the discriminant analysis of goat breeds

\begin{tabular}{|c|c|c|c|c|c|c|}
\hline & & Breed & Predi & $\mathrm{Me}$ & & Total \\
\hline & & & SAH & SOR & WAD & \\
\hline Original $^{a}$ & Count & SAH & 159 & 0 & 4 & 163 \\
\hline & & SOR & 0 & 171 & 0 & 171 \\
\hline & & WAD & 1 & 1 & 248 & 250 \\
\hline & $\%$ & SAH & 97.5 & 0.0 & 2.5 & 100.0 \\
\hline & & SOR & 0.0 & 100.0 & 0.0 & 100.0 \\
\hline & & WAD & 0.4 & 0.4 & 99.2 & 100.0 \\
\hline Cross-validated & Count & SAH & 159 & 0 & 4 & 163 \\
\hline & & SOR & 0 & 171 & 0 & 171 \\
\hline & & WAD & 1 & 1 & 248 & 250 \\
\hline & $\%$ & SAH & 97.5 & 0.0 & 2.5 & 100.0 \\
\hline & & SOR & 0.0 & 100.0 & 0.0 & 100.0 \\
\hline & & WAD & 0.4 & 0.4 & 99.2 & 100.0 \\
\hline
\end{tabular}

a. $99.0 \%$ of original grouped cases correctly classified.

b. $99.0 \%$ of cross-validated grouped cases correctly classified.

$\mathrm{SAH}=$ Sahel goats, $\mathrm{SOR}=$ Sokoto Red goats, $\mathrm{WAD}=$ West African Dwarf goats. 


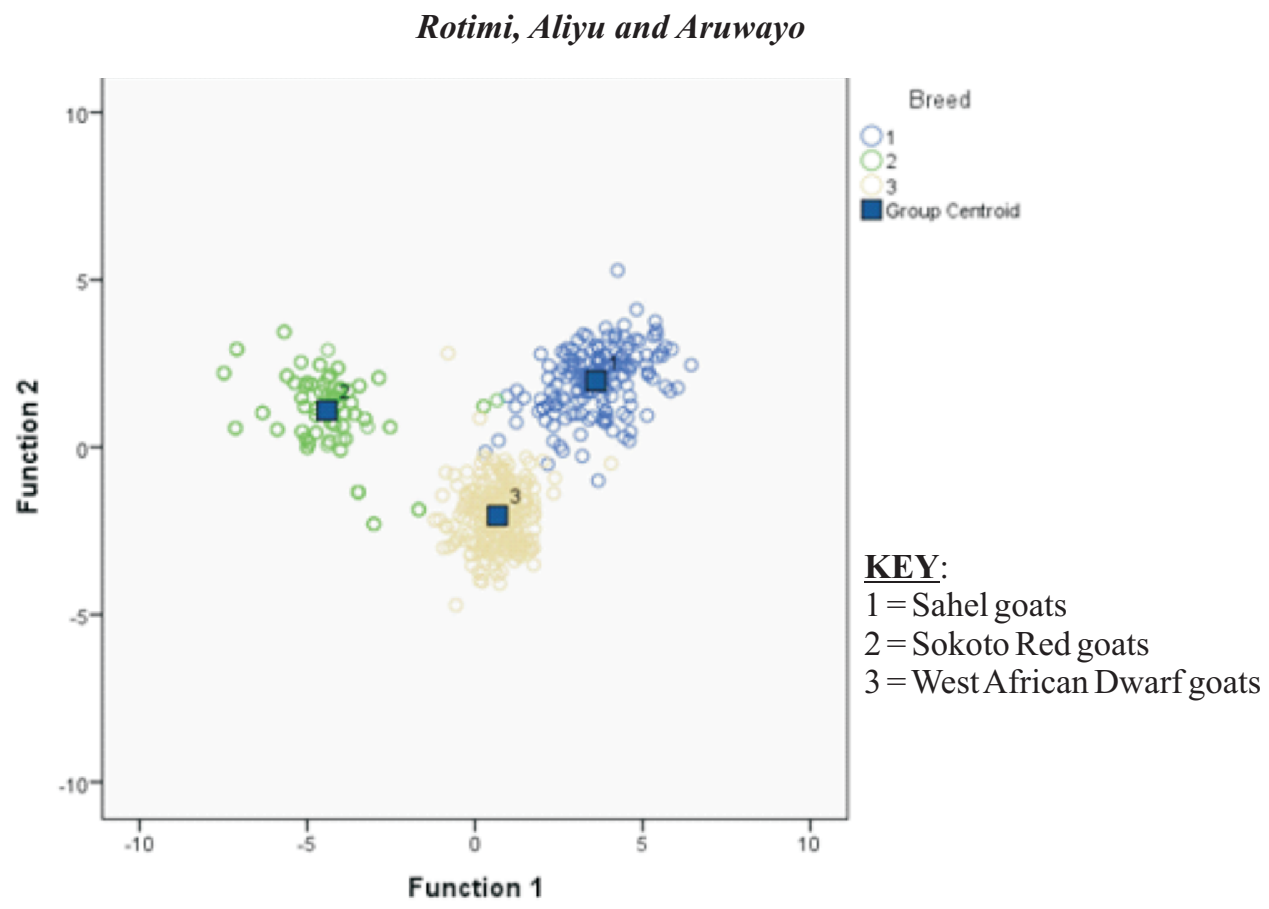

Figure 1: Canonical allocation of the morphological traits associated with individuals by breeds

\section{Conclusions}

The study showed that paunch girth and height at withers were the most discriminating variables to classify the three goat breeds. This might be valuable in field assessment, management and conservation of these goat breeds. However, genetic marker is needed to complement the information obtained from this study.

\section{Acknowledgements}

The authors are grateful to goat keepers from the study location, who willingly submitted their goats for this work.

\section{References}

Adebambo, A. O., Adebambo, O., Williams, J. L., Blott, S. and Urquart, B. 2011. Genetic distance between two popular Nigerian goat breeds used for milk production. Livestock Research for Rural Development, 23 (26).
Adeyinka, I. A. and Mohammed, I. D. 2006. Accuracy of body weight prediction in Nigerian Red Sokoto goats raised in North Eastern Nigeria using linear body measurements. Pakistan Journal of Biological Science, 9, 2828-2830.

Akpa, G. N., Ambali, A. L. and Suleiman, I. O. 2014. Body Conformation, Testicular and Semen Characteristics as Influenced by Age, Hair Type and Body Condition of Red Sokoto Goat. New York Science Journal, 6 (7), 44 $-58$.

Aziz, M. M. A. and Al-Hur, F. S. 2013. Differentiation between three Saudi goat types using size-free canonical discriminant analysis. Emir Journal of Food and Agriculture, 25(9), 723-735.

Chineke, C. A. 2000. Characterization of physical body traits of domestic rabbits in Humid Tropics. 
Proceedings $25^{\text {th }}$ NSAP Conference. Michael Okpara University of Agriculture, Umudike, 19-23 March, 237-238.

Delgado, J. V., Barba, C., Camacho, M. E., Sereno, F. T. P. S., Martinez, A. and Vega-Pla, J. L. 2001. Livestock characterisation in Spain. AGRI. 29, 7-18.

Dossa, L. H., Wollny, C. and Gauly, M. 2007. Spatial variation in goat populations from Benin as revealed by multivariate analysis of morphological traits. Small Ruminant Research, 73, 150-159.

Ebegbulem, V. N., Ibe, S. N. and Asuquo, B. O. 2011. Morphometric differentiation of West African dwarf goats in Southeastern Nigeria using discriminant analysis. Journal of Agriculture and Veterinary Science, 3, 29-34.

FAO 2000. World watch list for domestic animal diversity, 3rd edn (edited by ScherfBD), Rome, Italy. Pp726.

FAO 2012. Phenotypic characterization of animal genetic resources. FAO Animal Production and Health Guidelines No.11. Rome, Italy.

FA O S T A T 20018 . h t t p : / / http://www.fao.org/faostat/en/\#dat a/QA

Hirbo, J., Muigai, A., Naqvi, A. N., Rege, E. D. and Hanotte, O. 2006. The Genetic Diversity of Transcaucasian Native Sheep Breeds. Asian-Australian Journal Animal Science, 19(7), 943-952.

Ibe, S. N. and Ezekwe, A. G. 1994. Quantifying size and shape difference between Muturu and $\mathrm{N}^{\prime}$ dama breeds of cattle. Nigerian Journal of Animal Production, 21, 51-58.

Ibnelbachyr, M., Boujenane, I. and Chikhi, A. 2015. Morphometric differentiation of Moroccan indigenous Draa goat based on multivariate analysis. Animal Genetic Resources, 57, 81-87.

Jimcy, J., Raghavan, K. C. and Sujatha, K. S. 2011. Diversity of local goats in Kerala, India, based on morphobiometric traits. Livestock Research for Rural Development, 23(5).

Kunene, N., Nesamvuni, E. A. and Fossey, A. 2007. Characterization of Zulu (Nguni) sheep using linear body measurements and some environmental factors affecting these measurements. South African Journal of Animal Science, 37, 1120.

Ngere, L. O. 2006. A comparative study of structural variation between Red Sokoto and West African Dwarf goats in South West Nigeria. M.Sc Thesis. Department of Animal Science, University of Ibadan, Ibadan, Nigeria.

Ogah, D. M., Musa, I. S. and Yusuf, N. D. 2013. Prediction of Carcass weight from body measurements in West African Dwarf goat using canonical correlation analysis. Egyptian Journal of Sheep and Goat Sciences, 8(1), 75-79.

Okpeku, M., Yakubu, A., Peters, S. O., Ozoje, M. O., Ikeobi, C. O. N., Adebambo, O. A. and Imumorin, I. G. 2011. Application of multivariate principal component analysis to morphological characterization of indigenous goats in southern Nigeria. Acta Argiculturae Slovenica, 98(2), 101-109.

Popoola, M. A. and Oseni, S. O. 2017. Multifactorial discriminant analysis of cephalic morphology of indigenous breeds of rams in Nigeria. Proc. $42^{\text {nd }}$ Conf. Nig. Soc. for Ani. Prod. 26 $-30^{\text {th }}$ March. 
Landmark University, Omu-Aran, Kwara state, Nigeria.

Rotimi, E. A., Momoh, O. M. and Egahi, J. O. 2020. Relationship between body weight and morphological traits in Sahelian goats of Nigeria using path analysis, Mustafa Kemal University Journal of Agricultural Sciences, 25(3), 455-460.

SPSS 2011. Statistical Package for the Social Sciences. User's Guide: Statistics, Version 15.0. Institute, Inc., Cary, NC, USA.

Traore, A., Tambouraa, H. H., Kaborea Royob, L. J., Fernandezb, I., Alvarezb, I., Sangarec, M., Boucheld, D., Poiveye, J. P., Francoisf, D., Toguyenic, A., Sawadogog, L. and Goyache, F. 2008. Multivariate characterization of morphological traits in Burkina Faso sheep. Small Ruminant Research, 80, 62-67.
Yakubu, A., Salako, A. E., Imumorin, I. G., Ige, A. O. and Akinyemi, M. O. 2010. Discriminant analysis of morphometric differentiation in the West African Dwarf and Red Sokoto goats. South African Journal of Animal Science, 40(4), 381-387.

Yunusa, A. J., Salako, A. E. and Oladejo, O. A. 2013. Morphometric characterization of Nigerian indigenous sheep using multifactorial discriminant analysis. International Journal of Biodiversity Conservation, 5(10), 661-665.

Zaitoun, I. S., Tabbaa, M. J. and Bdour, S. 2005. Differentiation of native goat breeds of Jordan on the basis of morphos t r u c u r a 1 characteristics. Small Ruminant Research, 56, 173-182.

Received: $13^{\text {th }}$ May, 2021 Accepted: $15^{\text {th }}$ August, 2021 